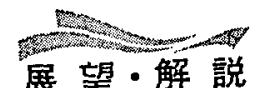

\title{
自動車の衝突大変形シミュレーション*
}

萩 原 一 郎**

\section{Collision-Large Deformation Analysis for Car Vehicle}

\section{Ichiro Hagiwara}

\section{1.はし゚めに}

自動車の交通安全問題は自動車が誕生して以 来，最重要なテーマとして各社で研究が続けられ てきている。その研究の内容は，1）事故を未然 に防ぐ事故回避性能 2) 衝突時の乘員の傷害低 減および車雨火药など二次災害からの安全確保に 関する衝突安全性能 3) 歩行者や他の車闭に対 する加害性を低減する性能とに大別される。そし て自動車の設計開発時には，おのおのの性能につ いて多岐にわたる実験確認掞よび電算シミュレー ションが実施される。このらち衝突安全性能のシ ミュレーションは,ここ2〜3年の間に,従来のマ スバネシミュレーションに加えてスーパーコンピ ュータを使用することにより大規模な解析が可能 となってきた。本稿ではこの点を中心に述べる。

\section{2. 自動車の衝突現象と解析シミュレーション}

衝突形態之しては前面, 後面, 側面, ロ一ル才 一バ等があり, 衝突の相手も車両, 固定壁面, ポ ール等さまざまある。いずれの場合も車両の衝㔖 現象はわずか数10～数100ミリ秒で終了する。こ の間にその運動ェネルギーを車両の変形で四収す る。この間のエネルギー吸收特性を向上させ，最 終的に乗員の衝撃度を軽減するために，衝突シミ ュレーションが行われている。シミュレーション には図1に示すように，まず，乗員挙動シミュレ ーションと車両衝突シミュレーションがある。前

*原稿受付1991年 2 月 1 日

**日産自動車 (株) 中央研究所
者は，シートベルトやェアバックで拘束された実 験評価用の人体模型（ダミ一）の頭部に発生する 加速度波形や胸部の加速度の大きさ等が求められ る。後者は，同図に示す上らに車両全体でのシミ ュレーションの他，ステアリング単体での衝撃解 析，ドアの静的な变形抵抗解析，ルーフの静的な 変形抵抗解析など，部品単体あるいは車両の一部 を対象にモデル化したシミュレーションもある。 そして，解析モデルとしては設計計画段階では， 簡略化したマスバネモデルなどが使用される場 合があるが現在ではシェル要素による詳細な有 限要素モデルで検討されるのが主流である。その 場合, 塑性域まで含めた, 大変形解析が実施され る。これらのシェル要素による王潰シミュレーシ ョンは衝突安全性の別の評洒項目である。耐損傷 性や修理性汇るそのまま適用できる。

耐損傷性は，車体に損傷（残留变形）を生じさ せない衝突条件のレベルを評価することである。 修理性では，市場での事故に対する修理費用を評

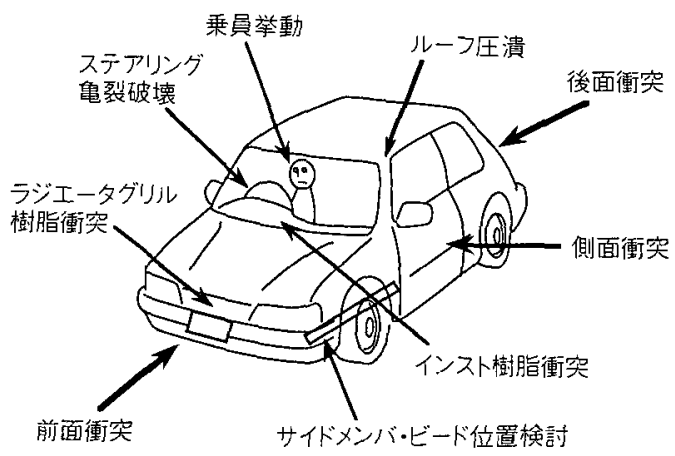

图 1 衝突安全に関する解析項目例 
価する。衝突レベルに応じて, 修理, 交換が容易 な部分から变形させ交換費用が高価な部品にはで きるだけ損傷が及ばないようにして修理費の軽減 を図るものである。

\section{3. 衝突シミュレーションの歴史}

事故の形態はさまざまであるが車両前面の衝突 事故が国内に沶いても $47 \%$ と最も多い。文の前 面衝突に関する現在の解析モデルの一例を図 $2^{21}$ に示す。同図でエンジン，タイヤなども分布系で 表現され要素数は 1 万程度に達する。スーパーュ ンピュータを用いても例光ば CRAYXMP-12で 15時間〜20時間の演算時間を要する大規模なモデ ルである。このモデルは車両全体がンェル要素に 分割され，一見，モデル作りは単純に見方る。し かし，この解析モデルは1970年前後からの各社の 多くの研究なくしては得られないものである。こ こで, 衝突シミュレーションの歴史をかけ足で振 り返る。

\section{1 第 1 期: マス・バネシミュレーション}

1967年，米国連邦安全基準（FMVSS）が発行 され数々の規定が設けられたことそして，1970年 日米政府間で調印された覚書きに基づき小型実験 安全車 (ESV) の開発が各社で進められたことが この面の研觉を大いに加速した。FMVSSが設定 されたあと, 直ちに対壁 $30 \mathrm{MPH}(48 \mathrm{~km} / \mathrm{h})$ 前 面衝勞に対沁した図 3 の解析モデルが開発され $た^{3)}$ 。車両は前半部, 後半部, パワーュニット部, リアアクスル部の四つに分割され，それらがフロ ントエンド・下部材，エンジン前方構造部材，ド ア，エンジンマウンティング部材等八つのバネで つながれている。そしてバネ特性は同図のように パターン化される。この解析モデルは，前面衝突

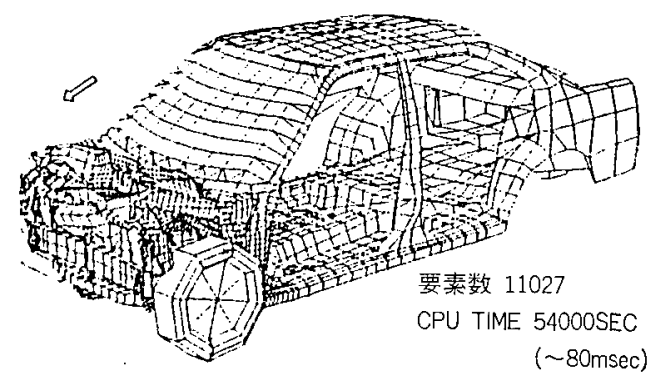

图 2 フル・スケールカー変形モード解析結果 ${ }^{2}$
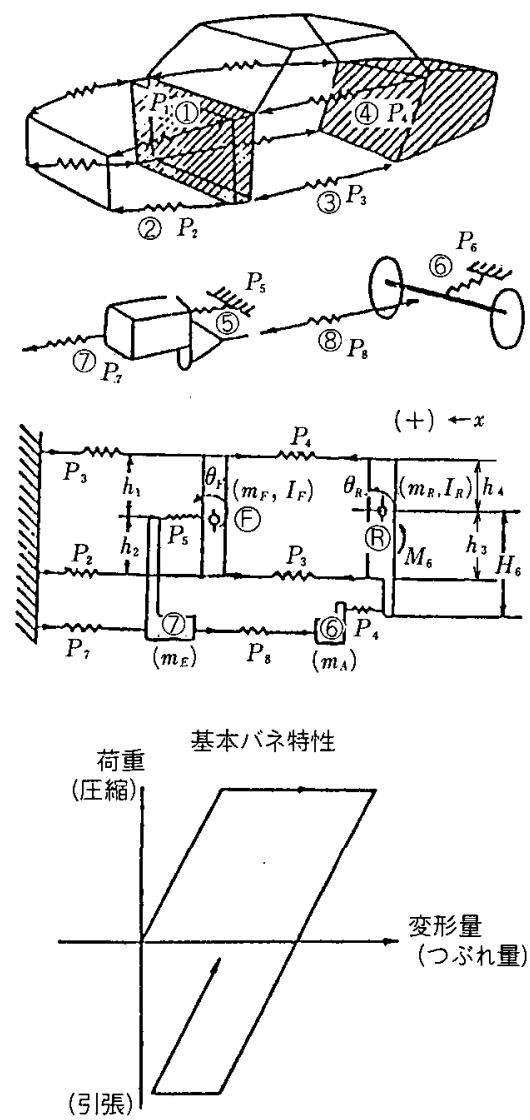

図 3 初期のマス・バネモデルと基本バネ特性

解析の最大のテーマである‘ステアリング後方移 動量' やフロントェンド（車両前部）とキャブメ イン（客室）の強度バランスのあり方, 力の伝わ り方, 衝突時に叔ける理想的な減速度波形等が求 められた。このように，バネ特珄さえ正しく求め れば，図 3 の簡単なモデルでもある程度満足でき る結果が得られるわけである。そのため，曲げ部 材や真直部材のエネルギー财収特性に関する研究 が活発となった。特に薄肉の箱型や八ット型断面 の真直部材の静的圧潰実験が数多くなされ荷重一 変位特性の実験式が求められて ‘゙ネ特性算出に利 用された。その中で Mahmood らの寒験式は は 最も広い範囲で利用が可能である。このあと，い くらかマスやバネの数は増えたが, 図 3 のモデル が基本となっている。

\section{2 第 2 期: FEM, FDM 梁要素の利用}

1973年前後の第 1 期石油ショック以後, 省資源, 
省エネルギが強くうたわれ，車両の軽量化の要求 は一層敦しいものとなった。それとともに，必要 な衝突解析の精度は一層高いるのとなった。そこ

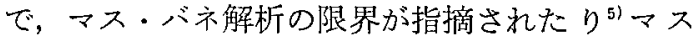
・ バネ解析のバネ特性算出の精度を向上すべく FEM PFDM の利用が試みられた。当時は市販 ソフトに優れたものが少なかったこともあり自社 開発も試みられた。まずシェル要素では例えば適 合要素等を利用すると弾塑性マトリクスが剛すぎ るという問題や面と面の接触を正しく追ってゆく のは困難であった。それ以上に，最大級の洲用機 を用いてもシェル要素では演算時間が長すぎると いう問題があった。そのため著者は $\mathrm{FEM}^{6)} て ゙$, $\mathrm{Ni}^{7)}$, Nakamura ${ }^{\mathrm{g})}$ は, FDM で梁要素のソフト を開発した。しかし，梁要素では大変形汇より断 面変形が生じた場合の影響を考虑することは困難 である。そのため，変形時のモーメントーたわみ 角線図を実験で求め，乙れを解析時使用する工 夫も行われだ，81。ただし，この場合でも梁要素 で使用される塑性マトりクスは基本的に塑性ヒン ジの考えで作成されて和り圧潰が中心となる問題 には不向きである。梁要素で一応の成果は得られ たものの上述の理由でシェル要素を使った効率の よい解析法が強く望まれるようになった。

\section{3 第 3 期 : スーパーコンピュータとシェル}

要素を用いた衝突シミュレーション

自動車メ一力の衝突解析担当者比とって，マス ・バネモデルのバネ特性を設計段階で正しく見積 もるための解析技術そしてマスバネ解析の限界を 打破すべく車両全体をシェル要素で解析できる技 術を見出すことが最大の課題であった。そして最 も重要なことは計算速度をいかに上げるかであっ た。スーパーコンピュータの出現とともに，それ にあった解析手法が整理された。HONDO，DY NA-3D，DYCAST/GAC，PAM//CRASH 等 が相次いで開発された。それら共通の中核となる 解析技術は次の 4 点と考えられる。

(1) 集中質量マトリクス括よび中心差分法の利 用 ${ }^{9 !}$

(2) スライディングインタフェースの利用101

(3) ラジアルリターンアルゴリズムの利用11

(4). 次数低減積分シェル要素の利用 ${ }^{121}$
これらの解析技術とスーパーコンピュータの利 用によって図 2 のような大規模モデルによる解析 が可能となったのである。そして，我々がねらっ ていた 1) 車両全体の変形モード 2) エネル ギー吸収分担率などの解析が設計段階で可能とな ってきた。上記項目で，スライディングインタフ ェースと次数低減積分シェル要素は解析精度の向 上にも笴与している。たとえば，図 4 は真直部材 の生漬解析で得られた荷重一变位線図と压潰モ一 ドであるがスライディングインタフェースの存在 で要素の貫通がなく正確な荷重一变位線図が得ら れている。スライディングインタフェースではあ らかじめ指定された面と面の接触の確認がなされ つつ解析が行われるため，接触確認を少なくした いがそれにはマス・バネシミュレーションで得ら れた知見が有効である。

つぎに次数低減積分シェル要素は著者が開発し た塑性関節点マトリクス ${ }^{13)}$ と同様にいわゆる‘口 ッキング現象”を回避するのに有効なようであ

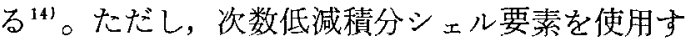
る場合, 解析モデルや衝突速度により図 5 に示す よらな稆エネルギーに無関係のアワーグラスモー ドが発生する点に留意する必要がある。これを抑
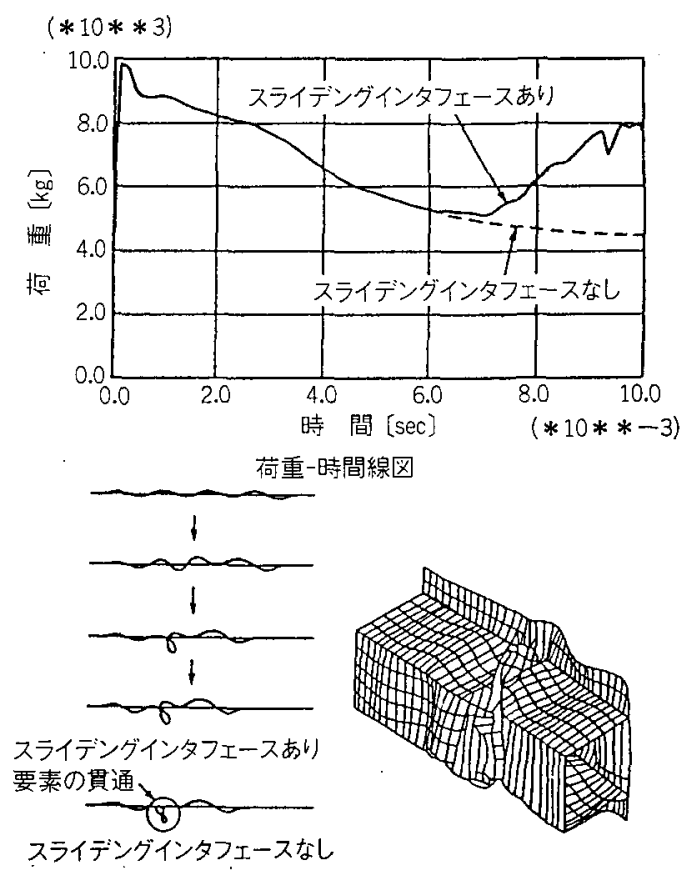

图4 スライディングインタフェースの効果 


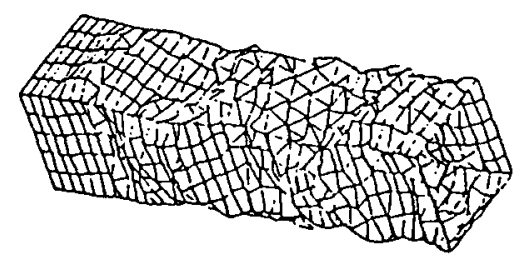

(a) コントロールなし

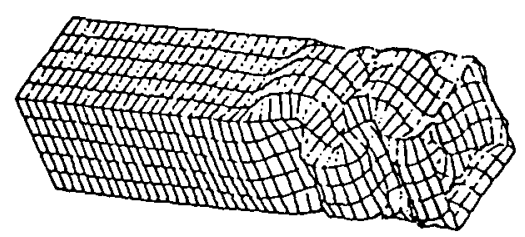

(b) コントロールあり

図 5 フローグラスコントロールの有無によ る聩モードの相遀

制するために途中で変形が急激に大きくなる部分 を細分割したり，アワーグラスコントロールファ クターを上げることが必要となる。以上かけ足で 衝突シミュレーションの歴史を述べたが次章でこ れからの前面衝突解析の基礎となるスーパーコン ピュータを用いたシェル要素による真植部材の压 潰解析について述べる。

\section{4. シェル要素を用いた箱型断面真直部材圧潰解 析}

車両の対壁前面衝突性能厄最も大きな影響を与 えるのはフロントサイドメンバーのフロントェン ド部の真直部分である。すなわち車体の変形が客 室内に及べば無拘束の乗員に傷害を与える危険な 事態となりえるため，車両前部の变形によって衝 突エネルギーを吸収しなければならない。車両前 部を構成する強度部材の中でるサイドメンバーの エネルギー吸収に対する寄与は大きい。サイドメ ンバーは薄肉の箱型または八ット型断面部材で, その形状はサスペンション等の位置関倸から客室 の下の所で曲がった形状となるが前部は荷重を上 げるため極力, 真直さが保たれる。そしてこの真 值部が折れないよう前端から順にアコーディホン 状に圧潰させることがサイドメンバーのエネルギ 一吸收効率を上げるために有效である。そこで車 両全体モデルで解析される前に, サイドメンバー 単体の圧潰解析がしばしば行われる。

\section{1 初期不整を得るための座屈解析とそれを利 用した解析}

ここでサイドメンバーを模擬した断面 $50 \mathrm{~mm} \times$ $50 \mathrm{~mm}$, 全長 $250 \mathrm{~mm}$, 板厚 $0.4 \mathrm{~mm}$ の正方形断 面真直部材の一端を完全固定し，自由端に $330 \mathrm{~kg}$ の重鍾が初速度 $30 \mathrm{~km} / \mathrm{h}$ で軸方向に落下するこ とを想定した動的圧潰解析について述べる15)。ま ず，初期不整なしで計算すると図6のように全体 に不規則な変形モードとなり荷重一变位特性る害 験と合致しない。そこで初期不整の与え方として 次の5ケースで検討を行った。

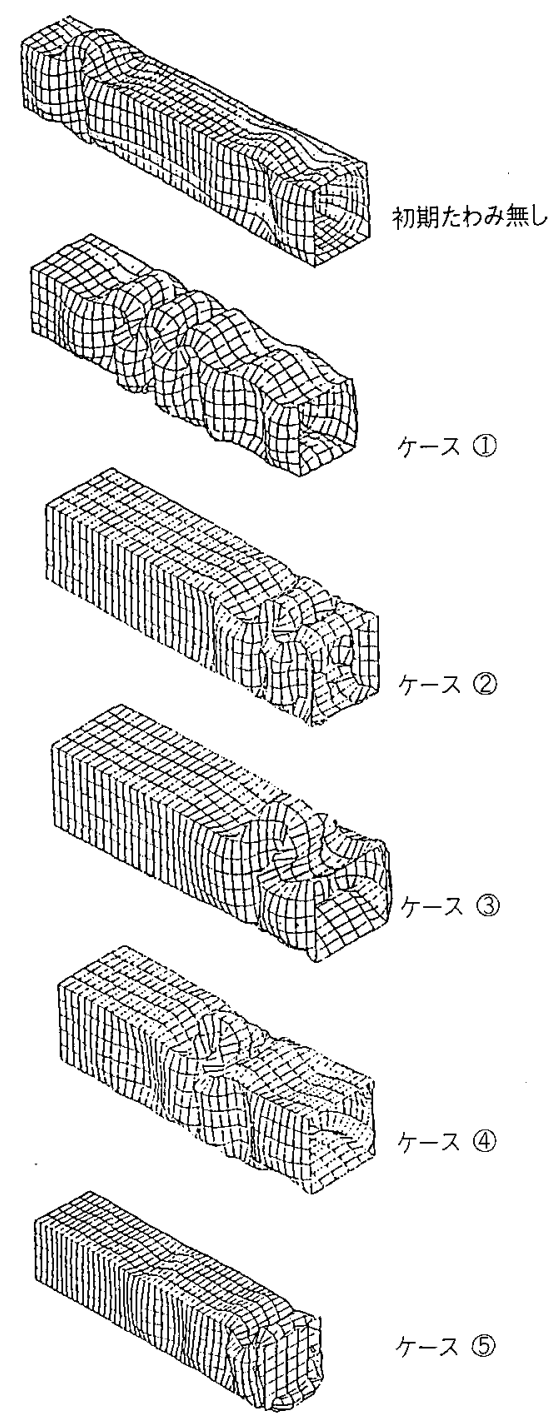

図6 各ケースに拉ける匟潰モード比較 
(1) 部材全体の軸方向に波長 $50 \mathrm{~mm}$ 正弦波 を入れる。

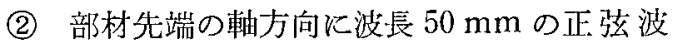
を半波長入れる。

(3) 部材全体に, 静的 1 次坐属モードを入れる。

(4) 部材全体に正規乱数により得られた不規則 な波形を入れる。

(5) 負荷入力を片当たりさせる。すなわち衝撃 端の節点のうち 5 分の 4 の節点のみに重錘 の質量を等分布させ強制速度を与兄る。

このうら妥当な結果が得られたのは静的 1 次座 屈モードを初期たわみとするるのであった。

Mahmood らに上り板厚と断面寸法との関係 によって，時に塑性座屈が生じ，部材の圧潰ピッ チや圧潰する断面形状が異なることが指摘されて いる゙が本方法でそれらの再現が可能となった。 その様子を図 7 に示す。同図で入は座屈の半波長 の長さ, $d=(a+b) / 2, a, b$ : 長方形断面の短辺

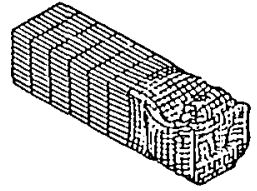

(1) Accordion-type

Regular Folding Mode $(\lambda<d)$ $50 \times 50(\mathrm{~mm}) \quad 1.6 \mathrm{t}$
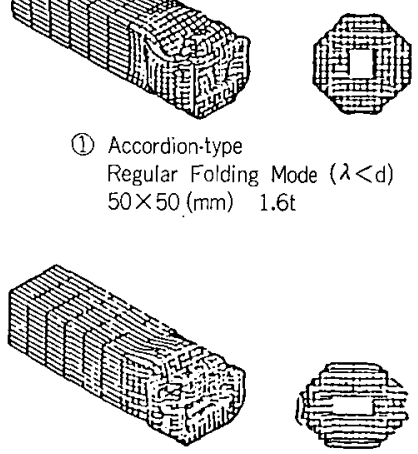

(2) Unstable Accordion-type Regular Folding Mode $(\lambda=d)$ $50 \times 50(\mathrm{~mm}) \quad 0.8 \mathrm{t}$
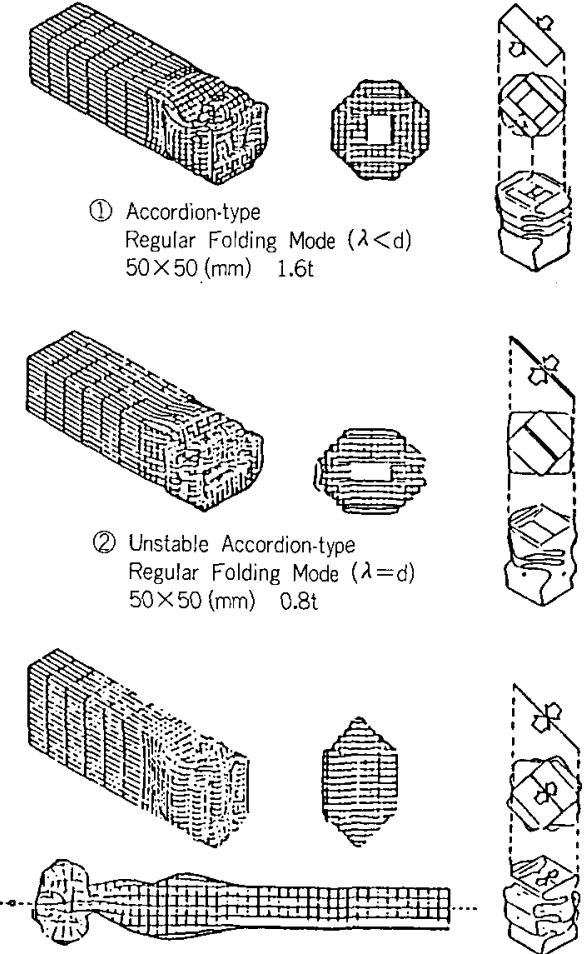

(3) trregular Folding Mode .Crumpling $70 \times 30(\mathrm{~mm}) 1.6 \mathrm{t}$

図 7 幾何学的形状と区濽モード'15
扣よび長辺の長さ。ただし，望性座屈が生じる場 合には臨界点での座屈解析に上って得ら机る 1 次 坐属モードを初期たわみとして入れる必要があっ た。まず，板厚の厚い(1)では，向かい合ら壁面同 上が干渉することなく安定したアコーディオン状 のモードを呈する（安定アコーディオン状モー ド)。

$\lambda=d$ となる(2)では向かい合ら壁面同士かなり 接近する。したがって，板厚が薄く角部の强度が 低い場合には折れを伴って压潰する場合がある (不安定アコーディオン状モード)。京た，矩形断 面部材の壁面が弾性座屈を起こす(3)では部材の向 かい合ら壁面同士が接触するために，折れを伴っ て在潰する(不規則折れモード)。(1)，(3)では板 厚と周辺長さが同じなため変形の途中るでは同様

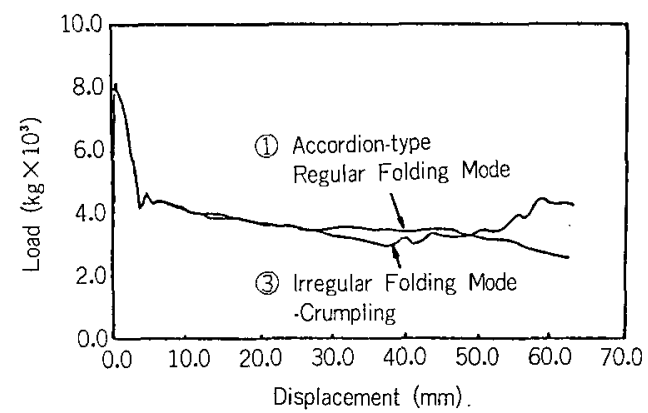

図 8 正潰モードと荷重の変化 ${ }^{15}$

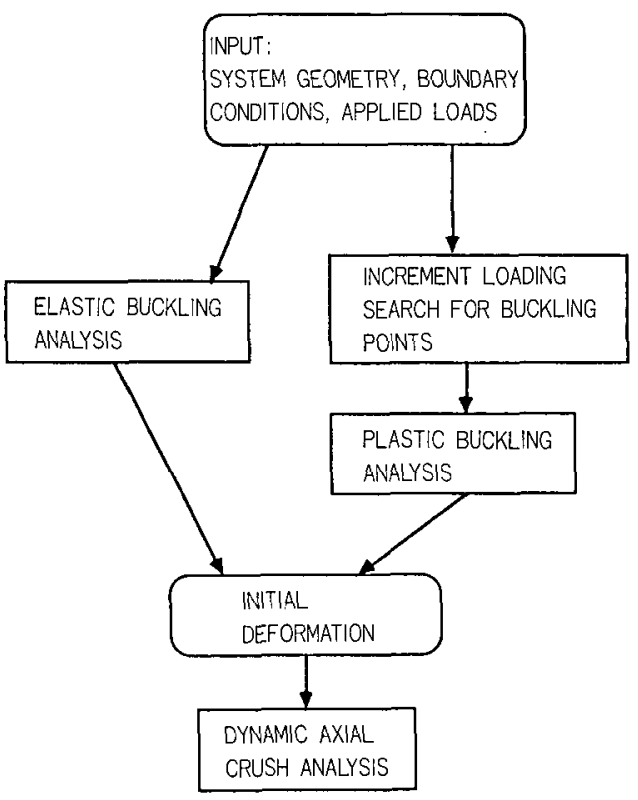

图 9 部材仕潰解析の流れ ${ }^{15}$ 


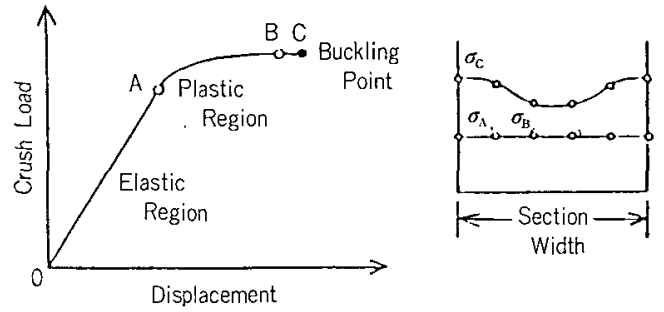

图10 壁面座屈に伴う荷重变化と応力分布 ${ }^{15)}$

の強度特性を示すが，(3)では図 8 に示すように向 かい合う壁面同士が接触したあと荷重值は(1)に比 し低くなってゆく。これらは，Mahmood らの 実験結果とよく対応する。以上の解析の流れを図 9 に示す。図 7 の(1)塑性座屈を伴らが，关の場 合を例に，図 9 の流孔を若下，理論的に述べる ${ }^{15)}$ 。

まず，“移動座標ラグランジュ形式 (Updated Lagrange)”による孤長增分法，4節点で面内の 積分点数が 1 の次数低減シェル要素を採用して静 的な圧潰解析を行らと，図10のような荷重変位線 図が得られた。座屈点すなわち，同図のC点を境 に荷重が格段に下がる。また代表断面の応力状態 を同図に，更にC点に達したときの部材全体の応 力図を口絵 5 に示す。これらにより座屈以後旮れ まで一様な応力状態であったものが断面中央の応 力は下がり角部の応力が高くなることがわかる。 C点あるいはC点を初めて通り過ぎた点のステッ プ数を $(n+1)$ とし， $(n-1)$ ステップおよび $n$ ステップでの剛性マトリクスを $\left[K_{n}\right],\left[K_{n-1}\right]$ とすると非線形座屈方程式は式(1)で得られる ${ }^{161}$ 。

$$
\left(\left[K_{n}\right]+\lambda[\Delta K]\right)\{\phi\}=0
$$

ここに，剛性マトリクスはミ一ゼスの降伏条件 と Prandl-Reuss の式から得られるものを使用 している。

$[\Delta K]=\left[K_{n}\right]-\left[K_{n-1}\right]$ 。座屈点の変位は $\left\{U_{c r}\right\}=\left\{U_{n}\right\}+\lambda\{\Delta \mathrm{U}\}$ と表わされる。

ここに，\{UU\} は式(1)の固有べクトルである。 仮想仕事の原理により，

$$
\{\Delta U\}^{T}\left\{P_{\mathrm{cr}}\right\}=\{\Delta U\}^{T}\left\{F_{c r}\right\}
$$

ここに,

$$
\begin{aligned}
\left\{F_{c r}\right\} & =\left\{F_{n}\right\}+\int_{U_{n}}^{U_{c r}}[K] \mathrm{d} u \\
& =\left\{F_{n}\right\}+\int_{0}^{\lambda}[K(\lambda)]\{\Delta U\} \mathrm{d} \lambda
\end{aligned}
$$

$$
=\left\{F_{n}\right\}+\lambda\left\{\left[K_{n}\right]+1 / 2 \lambda[\Delta K]\right\}\{\Delta U\}
$$

である。として，座屈荷重は式(4)で表される。

$$
\left\{P_{c r}\right\}=\left\{P_{n}\right\}+\alpha\{\Delta P\}
$$

ここに, $\{\Delta P\}=\left\{P_{n}\right\}-\left\{P_{n-1}\right\}, \alpha=\left(\lambda\{\Delta U\}^{T}\left\{\left[K_{n}\right]\right.\right.$ $+\lambda[\Delta K] / 2\}\{\Delta U\}) /\left(\{\Delta U\}^{T}\{\Delta P\}\right)$ である。

\section{2 開発した手法による部材圧潰のメカニズム の解析 ${ }^{17\}}$}

薄肉箱型断面部材のアコーディオン状圧潰の過 程は上記手法により詳細に分析することがでさ る。図11は部材の圧潰モード，図12は圧潰時の荷 重履歴を示す。まず，部材の断面を構成する壁面 のらち，最も座屈強度の低い壁面で最初の局所座 屈が起こる（図11 a)。この座屈によって壁面に 橈みが生じ，部材の角部に応力が集中する（図11 b)。やがて角部は降伏し，壁面の暁み炕上り稜 線部が屈服する（図11 c)。この点が最大発生荷 重点である(図12 a)。部材は座屈波長（半波長） 分の壁面を折り疊みながら压潰していく。この壁 面が折り盢まれると，次の壁面の変形が始まる （図12b)。乙かし，2回目以降の荷重の極大值 は, 前回の変形により壁面に橈みが生じているた めに, 1 回目の最大荷重に比べて低い值となる (図12b)。

任意断面形状部材では，㞋潰初期にはアコーデ ィオン状の壁面座屈波形が生じるが，軸方向の強 度に若干の片寄りがあるため，一般に図13 a に示

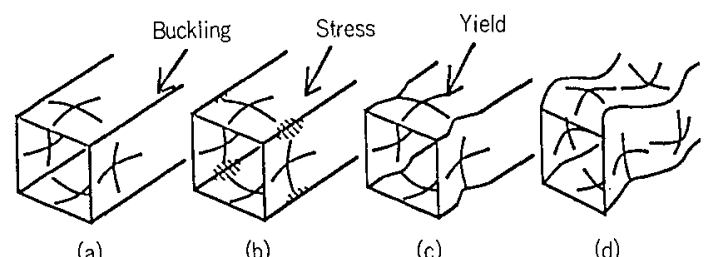

(a)

(b)

(c)

(d)

図11 部材の王濱モード17)

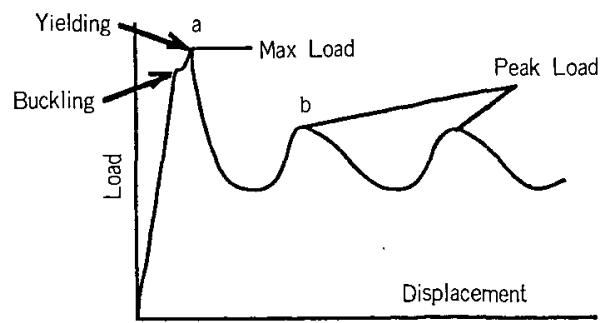

図12 部材の王潰時の荷重履歴 ${ }^{17}$ 

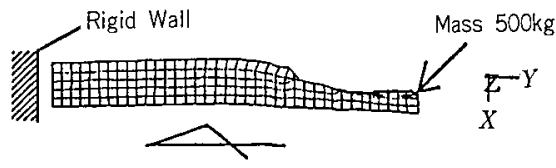

Velocity $35 \mathrm{mph}$

$0 \mathrm{msec}$
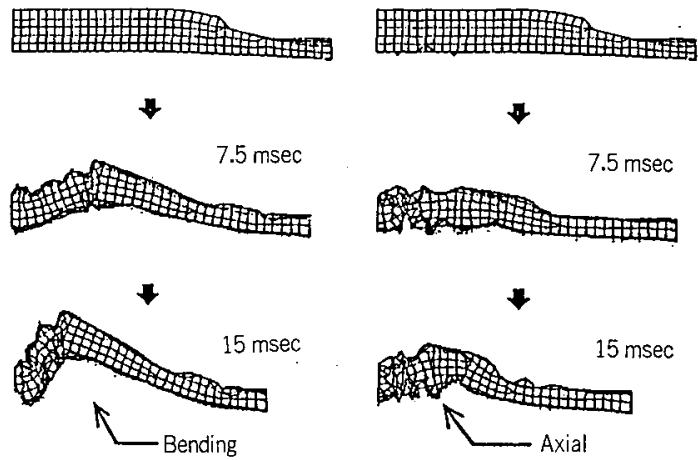

(a) Without Beading

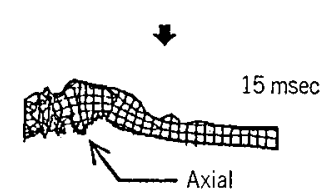

(b) With Beading

図13 解析モデルと衝撃王潰解析結果 ${ }^{17}$ 一王潰モート

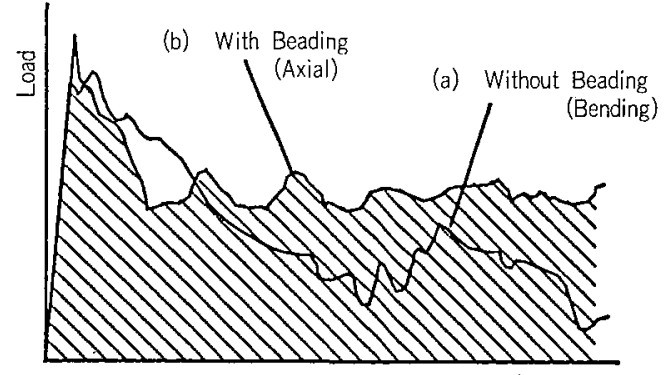

Displacement

図14 衝撃圧潰解析結果一荷重履歷 ${ }^{17}$

すように折れ曲がる傾向が強い。部材の座屈波形 に合わせて適切にビードを配置すると，部材をア コーディオン状圧潰に誘導することができる（図 $13 \mathrm{~b}$ ）。図14の荷重履歴の曲線で囲まれる部分の 面積が，部材の圧潰により吸収されたエネルギー 量に相当する。折れ曲がりモードに出けるエネル ギー吸収量は, 部材の折れ曲がりの発生以後は極 端に低下寸る(図14a)。一方，アコーディオン 状圧潰モードにおけるエネルギー吸収量は，安定 して高い値であることがわかる(図14b)。むた 荷重履歴の最大圧潰荷重点近傍を詳細に観察する と，ビードを設置したことにより部材が壁面座屈 の分岐経路に確実に誘導されていることがわかる （図15）。すなわち，ビードなし部材では壁面座屈

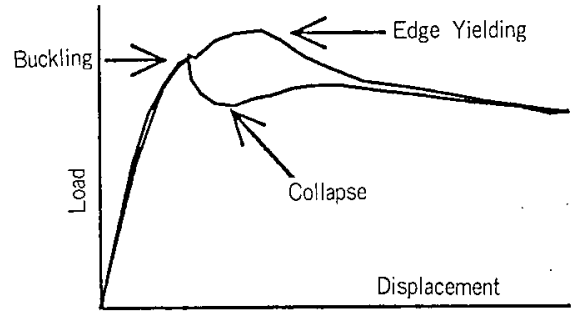

図15 荷重履歷の分岐点付近の詳細 ${ }^{17}$

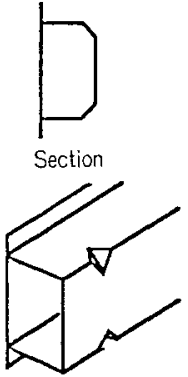

(a) Edge

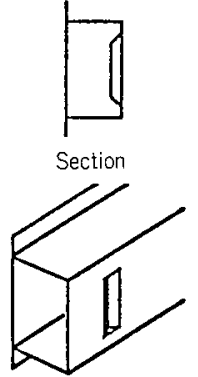

(b) Concave

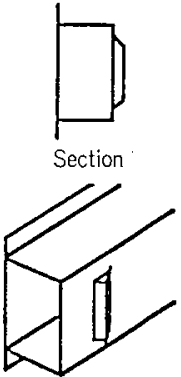

(c) Convex
図16 潰れビード外観図 ${ }^{17}$

以後も，稜線部屈服に至るまでにさらに荷重の上 昇があるため，屈服時には部材の全体的な变形 （折れ曲がり）が連成する傾向にある。ビード設 置部材では壁面座屈以後，角ビードの効果により 稜線部が直ちに屈服するので，壁面座屈による分 岐経路がそのまま圧潰の荷重复歴となる。以上の 解析手法で図16の三つのビードの適切な配置法と それぞれの定量的な効果の分析が可能となった。

\section{4. シェル要素を用いた車両の衝突シミュレーシ ヨン}

前面衝突時の乗員保護にあたっては，車両の生 潰特性と乗員拘束装置の拘束特性が重要となる。 両者のマッチングにより，その車両の基本的乗員 保護性能が決まる。たとえば、コンクリート壁に 車両が衝突する際，車両の圧潰反力 $F$ により車両 の運動エネルギーは失われ，停止する。その際， 乘員は初速度 $V_{0}$ から速度 0 となるまで，車両前 部の潰れ量 $L$ と居室内の乗員移動量 $I$ の和を移動 する。この距離が長いほど乗員の平均減速度は小

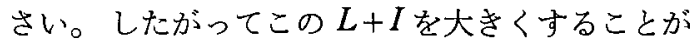
必要である。

一方，車両前部の潰れ量を増すことは，度を越 
すと居公内の乗員の移動可能空閒を縮めることと なる。また，居室内での乗員の前方移動量が度を 越すと，ステアリングホイールなど2 次衝突を引 き起しす。したがってこれらのバランスを図り， より完成度の高い試作車を設計するため衝突シミ ュレーションは威力を発揮することとなる。

さて，図 2 の車両前面衝突モデルは約 12000 節 点で構成されている。前面衝突の車両化潰シミュ レーションで特徵的なことは，エンジンルーム内 に配置されるェンジン，トランスミッション，ラ ジェータ，サスペンション等のコニット同志， るいはダッシュパネル等の車体鋼板部材との接触 問題が現象を大きく支配していることである。し たがって，これらを詳紐にモデル化することが実 車实験の結果を再現するポイントの一つとなる。 またフフロントサイドメンバー等の重要な閉断面 部材は他の車体部材よりも細密なシェル要素で構 成し，王潰モードの再現に留意する必要がある。

図 2 には圧潰形状が示されているが，図17に車 両減速特性を示す。実車実験の压潰特性を良好に 再現していることがわかる。上記の車雨王潰シ ェレーションあるいは笑車実験により車両の圧潰 特性がわかると，居室内拈いて拘束装置昫束 された乗員がどのような力を受け，どのような挙 動を示すかを乗員挙動シミュレーションにより再 現することになる。ここでは, 前述の車両圧潰シ ミュレーションの結果得られる減速特性, ダッシ ュパネル変位等が, 本シミュレーションの入力条 件となる。乗員挙動シミュレーションでは, 通常, 剛体要素を回転ばね特性を持つヒンジで結合して ダミ一モデルを構成し，これを拘束装置（シート ベルト，シート等)のば权特性をもって支持する。 図18k，典型的な 2 次元のダミーモデルを示す。

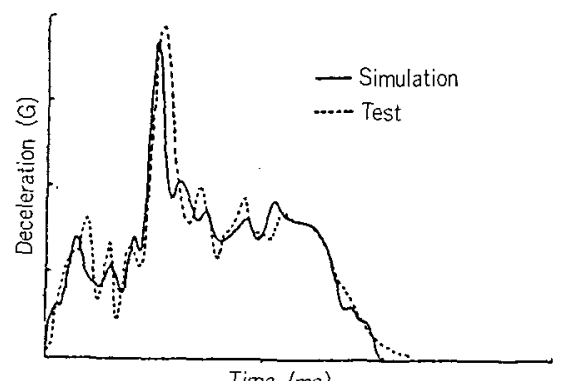

図17軹両圧潰特性の計算結果 ${ }^{2}$
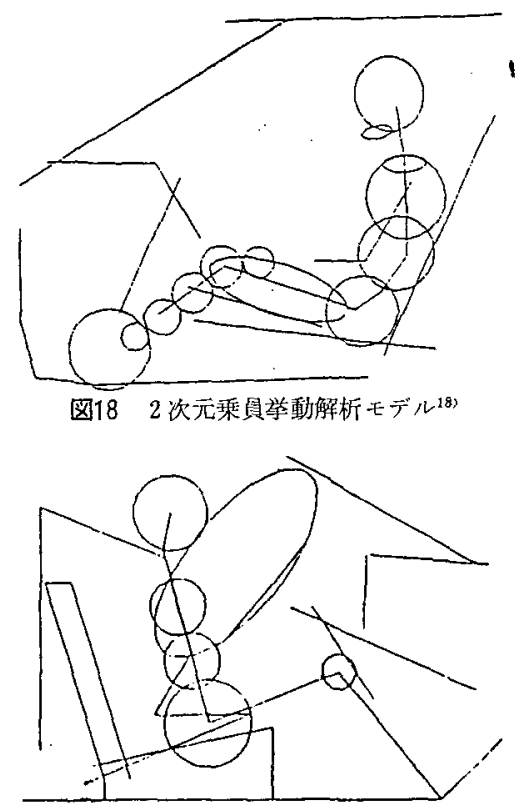

図19エアバック系のシミュレーション結果 ${ }^{183}$

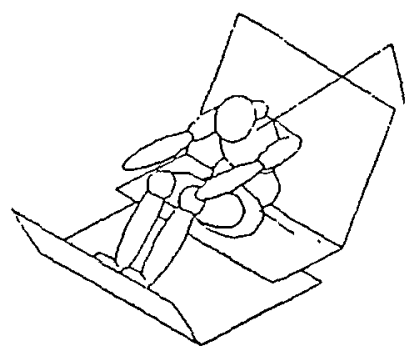

图20 3 次元乗負挙動モデル181

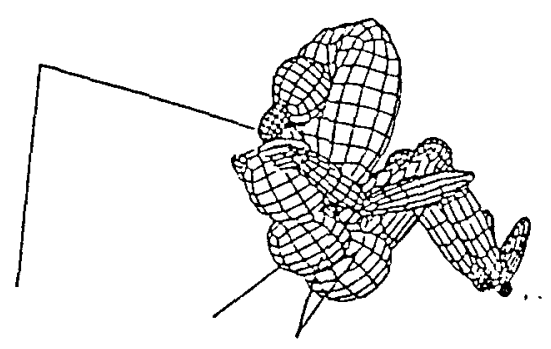

図21 有限要素解析之の結合例 ${ }^{18}$

高速衝突時の挙動を扱うため, 胴部も上胴部と 腰部に分割している。図19に拘束装置としてェア バッグを系に持つモデルによるダミ一挙動の計算 結果を示す。正面衝突であれば，このよらに簡単 な2次元モデルで現象を十分に扱い得る場合が多 い。拘束系のさらに詳細な検討，あるいは斜め衝 突などを扱ら際には3次元ダミーモデルを用い る。図20に典型的な 3 次元ダデミーモデルと挙動 
予测結果を示す。

また最近では，乘員挙動シミュレーションと動 的有限要素シミュレーションを結合して使用する 試みもなされている。図21にその一例を示す。本 例では，ェアバック袋体をシェル有限要素でモデ ル化し内王を与兄て動的に展開し，そこへダミー 上体をコンタクトさせている。この際，ダミーの 挙動は前述の 3 次元挙動モデル比よるシミュレー ションで時々刻々算出し，エアバック展開シミュ レーションの各タイムステップに和けるダミー上 体の位置の定義に用いている。

以上車両の前面衝突解析について述べたが，側 面衝突解析や後面衝突解析为鋭意進められてい る ${ }^{18)}$ 。しかしここでは紙面の関係上，省略する。

\section{6. まとめ}

まず，事故の形態として最も件数の多い前面の 衝突解析の䄳史を述べた。その中で，衝突特性を 大きく左右なるフロントサイドメンバの圧潰特性 解析の精度の向上や車両全体の衝突特性解析の精 度の向上のため, 塑性大変形を技えるシェル有限 要素の解析の笑現がいかに期待されたかを記し た。この解析を可能にしつつあるのは, スーパー コンピュータなどのハードウェアの進歩とともに 解析技術の進歩にも負らところが大きいが，その 主な解析技術を述べ，それぞれの位置付けを明示 した。DYNA/3D P PAM/CRASHなどスー パーコンピュータ向きに相ついで開発された代表 的な衝笑解析コードも必ずしもとの使い方は容易 ではない。例之ばフロントサイドメンバのェネル ギー吸収特性を向上するために設けられるビード の入ったモデルの解析を正確に行うことは困難で あることもその一例である。それを可能にする藷 者らの解析技術を述べ，これにより，ビードの設 置位置の適正化子得られることを述べた。このよ うに，さらに微に入り，細に入った解析を遂行す るためには，まだまだ多くの課題も残されてい
る。

上記の他，1)解析時間の短繀 2) 解析モデル作 成工数の低減も重要な課題である。今後もさらに 検討を加えていきたい。

\section{参考文献}

1) 父通統㖕（昭和61年版)，1987

2）高橋，奥山，下村，佐藤：大変形 FEM 解析以上る衙突シ ミュレーションの有効性，日産技報，24，p. 196,1988

3) 三浦，川村：自動車の衝突安全性に関して一変形機構の解 析，日姣技報，3，p. 3,1968

4) H. F. Mahmood and A.Paluszny: Management, SAE Paper 811302, 1981

5）例光ば，萩原：シミュレーションによる街突解析，自動車 技術, 33-3, p. 154, 1979

6) I. Hagiwara, Y. Sasakura, T. Nakagawa and Y. Kajio: SAE Paper 811476, 1981

7) C. M. Ni and K. H. Lin: AIAA Paper, 77-310, 1984

8) K. Nakamura and Y. Wakasa: SAE Paper 840450, 1984

9) T. Belytchko and W. L. Mindle: Computer and Structures, 12 , p. 805,1980

10) S. Ahmad, B. M. Iron and O. C. Zinkiewicz: International Journal for Numerical Methods in Engineering, 2, p. 419, 1970

11) R. D. Krieg and S. W. Key: Computational and Engineering Aspects (ASME, NY), p. 125, 1976

12) J. O. Hallquist, G. L. Goudreau and D. J. Benson: Computer Methods in Applied Mechanics and Engineering, Vol. 51, p. 107, 1985

13) 中川, 萩原, 棍尾: 車体バネル構造の大たわ強度解析, 自技会削剧集，851，p. $191 ， 1985$

14）萩原，藤原，津田，佐藤：箱型断面真直部材の效率的な玨 潰解析手法の開発，日産技報論文集，p. 25,1988

15）筄原, 津田, 佐藤：有限要素法に上る薄肉箱型断面真直部 材の衝撃压湍解析，日本機珹学会諭文集 (A編)，55巻514 号, p. 1407,1989

16) Fujikake, M.: A Simple Approach to Bifurcation and Limit Point Calculations, International Journal for Numerical Methods in Engineering, Vol, 21 (1985), p. 183

17）北川, 萩原, 津时：有限要素法による薄肉任意断面形状部 材の衝整王瀕解析，日本機械学全論文集 (A編)，57卷537 装, 1991

18）例えば，二俣：自動車鬥発に和ける衝突シミュレーション の利用について, 自動草技術会ンンポジウム, 自動車の計 算力学々 CAE 技術, p. 30,1990 


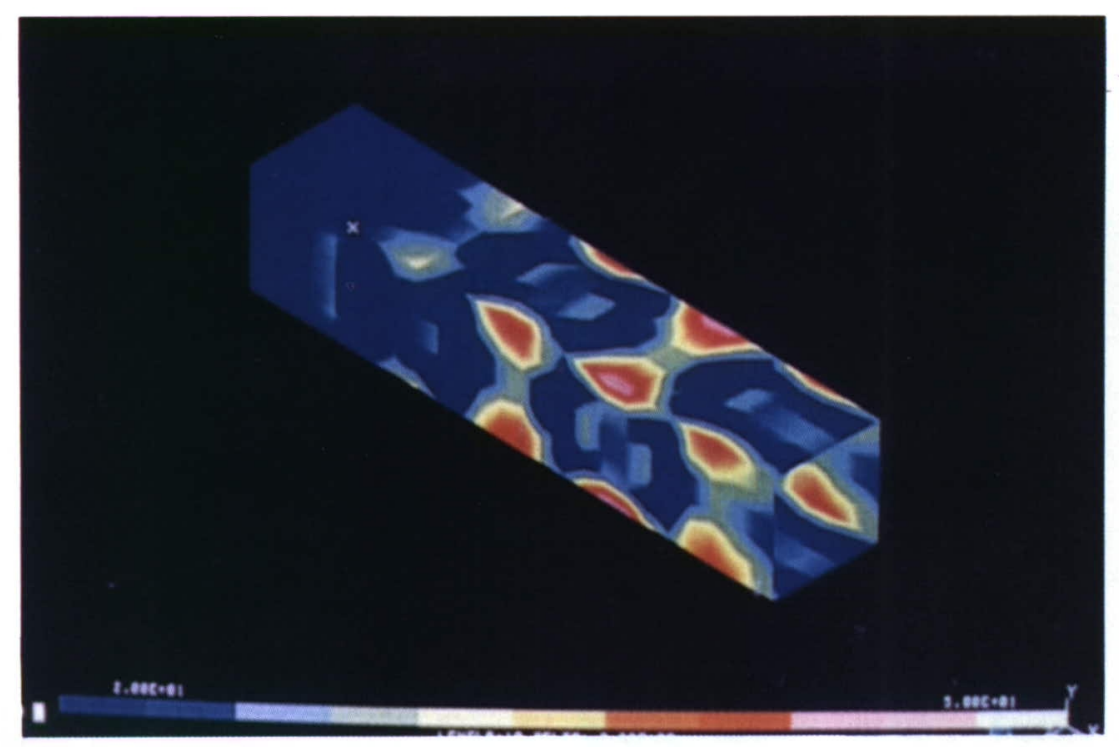

口絵 5 C点に達したときの部材全体の応力図 ${ }^{15)}$ (本文88頁参照)

（日産自動車(侏) 萩原一郎）

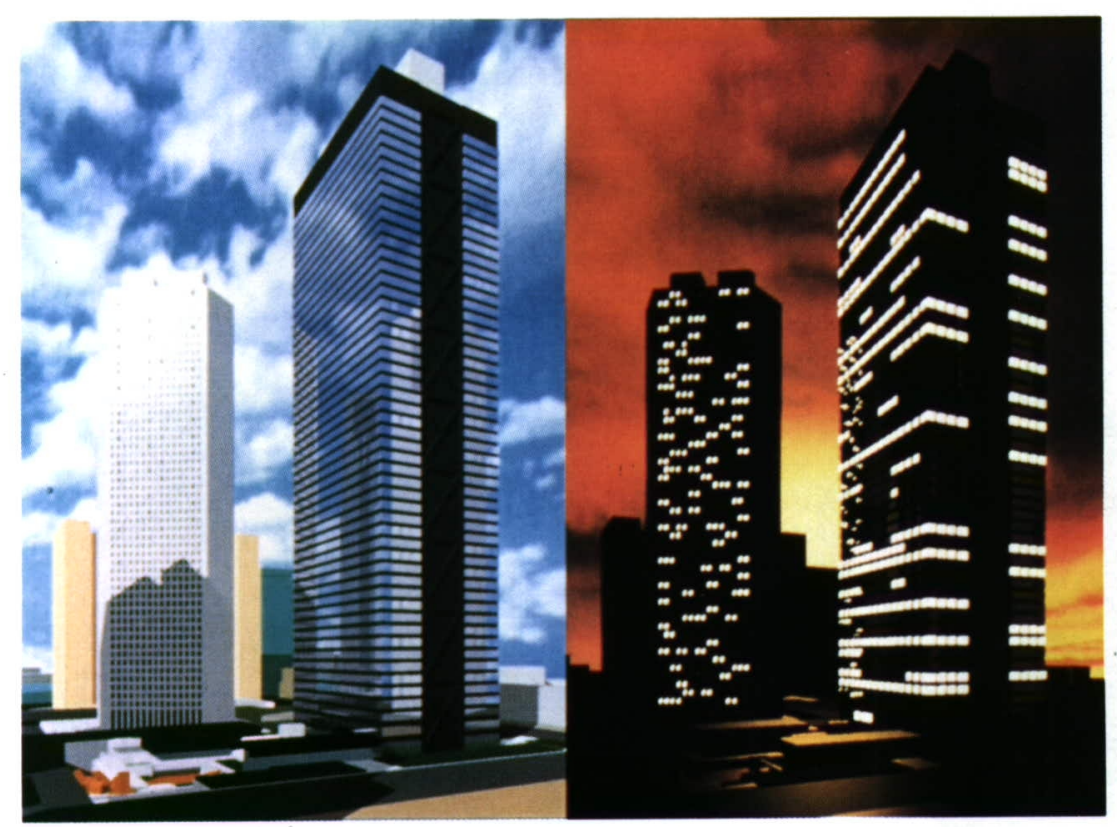

口絵 6 影観シミュレーションの例（本文97頁参照)

(鹿島建設(侏) 早川 真, 堀越清視, 是永雄二, 笠原信一, 佐藤正章) 